\title{
Grapevine Pinot gris virus variants in vines with chlorotic mottling and leaf deformation
}

\author{
Monica Marra ${ }^{1} \cdot$ Annalisa Giampetruzzi $^{1}$ - Raied Abou Kubaa ${ }^{2} \cdot$ Enrico de Lillo $^{1} \cdot$ Pasquale Saldarelli $^{2}$ (D)
}

Received: 7 August 2019 / Accepted: 1 October 2019 / Published online: 22 October 2019

(C) Società Italiana di Patologia Vegetale (S.I.Pa.V.) 2019

Grapevine Pinot gris virus (GPGV) was initially discovered in Trentino, Italy where it was associated with symptoms of chlorotic mottling and leaf deformation (GLMD). Then, this virus was reported in all the main grape growing areas worldwide (Saldarelli et al. 2017), which is an indication of the dissemination of uncontrolled propagation materials, likely favoured by the existence of GPGV variants not associated with disease symptoms (Saldarelli et al. 2015). Moreover, strong evidence exists that the virus is transmitted in the field by the mite Colomerus vitis (Pagenstecher 1857) (Malagnini et al. 2016). During a survey of a vineyard in Avellino, Campania, Italy a severe mite infestation was observed on vines of the cv. Falanghina. Vines were tested by RT-PCR for grapevine leafroll-associated virus 1, 2 and 3 (GLRaV-3), grapevine fanleaf virus (GFLV) and grapevine rupestris stem pitting-associated virus (GRSPaV) (Saldarelli et al. 2015), and by realtime RT-PCR for GPGV (http://sito. entecra.it/portale/cra_manuali_dettaglio.php?id_manuale= $23504 \&$ lingua=IT). GPGV was found in four out of 12 vines tested in single infection while one was co-infected with GLRaV-3. Four out of the five GPGV-positive vines showed GLMD symptoms and one was asymptomatic. In addition, GPGV was found in four out of 12 three-year-old vines of cv. Negramaro grafted on rootstock $1103 \mathrm{P}$ in a vineyard in Nardò, Lecce, Italy. The virus was present in multiple infection with GLRaV-3, GFLV and GRSPaV. GLMD symptoms were observed in four out of five GPGV positive vines.

Pasquale Saldarelli

pasquale.saldarelli@ipsp.cnr.it

1 Dipartimento di Scienze del Suolo della Pianta e degli Alimenti, Università degli Studi di Bari, via Amendola 165/A,

70126 Bari, Italy

2 CNR Istituto per la Protezione Sostenibile delle Piante, via Amendola 122/D, 70126 Bari, Italy
Sequence analysis of two amplicons from Falanghina and one from Negramaro using DetF/DetR primers (Saldarelli et al. 2015) showed that all three GPGV isolates carried the distinctive $\mathrm{C} / \mathrm{T}$ polymorphism in the movement protein gene and belonged to the phylogenetic group with asymptomatic isolates according to Saldarelli et al. (2015). The finding of asymptomatic GPGV variants was unexpected because most vines selected for this study manifested typical GLMD symptoms. This stresses the need to study the association of GPGV with symptoms, and cultivar susceptibility to GPGV infection.

\section{References}

Malagnini V, de Lillo E, Saldarelli P, Beber R, Duso C, Raiola A, Zanotelli L, Valenzano D, Giampetruzzi A, Morelli M, Ratti C, Causin R, Gualandri V (2016) Transmission of grapevine Pinot gris virus by Colomerus vitis (Acari: Eriophyidae) to grapevine. Arch Virol 161(9):2595-2599

Saldarelli P, Giampetruzzi A, Morelli M, Malossini U, Pirolo C, Bianchedi P, Gualandri V (2015) Genetic variability of grapevine pinot gris virus and its association with grapevine leaf mottling and deformation. Phytopathology. 105(4):555-563

Saldarelli P, Gualandri V, Malossini U, Glasa M (2017) Grapevine Pinot gris virus. In: Meng B, Martelli GP, Golino DA, Fuchs M (eds) Grapevine viruses: molecular biology, diagnostics and management. Springer International Publishing, pp 351-363

Publisher's note Springer Nature remains neutral with regard to jurisdictional claims in published maps and institutional affiliations. 